\section{Smakte det?}

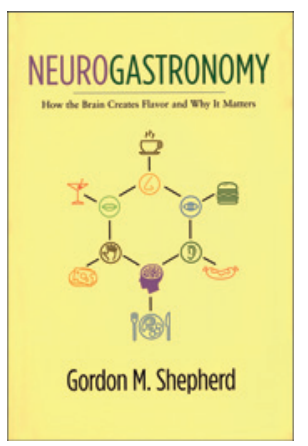

\section{Gordon M. Shepherd}

\section{Neurogastronomy}

How the brain creates flavor and why it matters. 265 s, ill. New York, NY: Columbia

University Press, 2012. Pris USD 25

ISBN 978-0-231-156910-4
Smaken av maten sitter ikke i maten, men dannes i vår egen hjerne. De personlige smaksopplevelsene bestemmer både hva slags mat vi velger i lengden, og hvor mye av den vi spiser. Det har lenge undret meg hvorfor disse enkle fakta er fraværende i de fleste diskusjoner om mat, dietter og ernæringspolitikk. For å kunne forstå - og påvirke - spiseatferd både hos den enkelte og på samfunnsnivå er det helt avgjørende å forstå hvordan hjernen lager mentale representasjoner knyttet til lukt, smak og relaterte sanseopplevelser, hvordan smakspreferanser dannes og vedlikeholdes i hjernen, og hvordan alt dette påvirker valg og vaner.

Denne boken er, blant annet, et forsøk på å belyse problemstillinger som disse. Gordon M. Sheperd er en høyt sitert nevroforsker, bl.a. innen basal luktforskning. Han er professor i nevrobiologi ved Universitetet i Yale og tidligere sjefredaktør i Journal of Neuroscience.

En av forfatterens hovedteser er at det tradisjonelle fylogenetiske premiss om at lukt er mindre viktig hos mennesker enn hos dyr er feilaktig. Han postulerer at lukt som sansefenomen er mye viktigere for å forstå menneskelig atferd enn det man til nå har ment.

Forfatteren begynner med en gjennomgang av grunnleggende luktbiologi, fra den fylogenetiske utviklingen av ansiktskraniet, via den viktige forskjellen mellom retronasal og orthonasal lukt, og til sammenhengen mellom lukt, smak og det kombinerte resultat, «flavor», som vi underlig nok ikke har noe norsk ord for. Deretter gjennomgår han hvordan hjernen ut fra de sensoriske signalene skaper og lagrer «luktbilder». Mye taler for at denne prosessen likner på hvordan hjernen gjenkjenner og lagrer ansikter, ikke i sine enkeltkomponenter, men som spatiale, komplette bilder. Det forklarer hvorfor vi er like gode på å gjenkjenne lukt som vi er ordfattige når vi skal beskrive den: Du gjenkjenner straks din bestemors ansikt blant 100 andre bestemødre, men er ikke i stand til å beskrive ansiktet slik at andre ville ha kjent henne igjen. På samme måte gjenkjenner du straks lukten av ananas, men er ikke i stand til presist å beskrive den slik at andre forstår hvilken lukt det er.

I siste halvdel går forfatteren gjennom det omfattende nevrobiologiske grunnlaget for det han kaller «the human brain flavor system», og de grunnleggende mekanismene for hvordan dette skapes, vedlikeholdes og endres av genetiske og miljømessige faktorer. Denne delen kan nok i en del passasjer oppfattes som noe tungt tilgjengelig for lesere uten nevrofaglig bakgrunn. Det er synd, for mye av dette er ny nevrovitenskapelig kunnskap som er svært relevant for forståelsen av aktuelle samfunnsfenomener som bl.a. fedmeepidemien og hurtigmatkjedenes fremvekst.

Shepherd har solid faglig bakgrunn for å skrive denne boken. Det gir fremstillingen et eget preg når forfatteren, født i 1933, refererer til personlig bekjentskap og faglig samarbeid med bl.a. flere kjente nobelprisvinnere. Samtidig kan dette også ses som noe av svakheten, idet fremstillingen i enkelte deler bærer preg av hans ønske om å skrive luktens - og dermed også sin egen - forskningshistorie i navn og anekdoter. Av og til kunne man ønske seg en noe bredere, mindre personlig fremstilling med mer vekt på de deler av den nevrogastronomiske forskningen som ikke bare primært dreier seg om lukt.

Det må også ses som et ønske om historieskriving når forfatteren tar æren for å ha oppfunnet termen nevrogastronomi, i en artikkel fra 2006. Der må han nok arresteres, for selv undertegnede anmelder kan dokumentere å ha holdt foredrag om nevrogastronomi helt fra 2005 - og jeg er helt sikkert ikke alene i verden om det.

Alt $i$ alt er boken en grundig og god innføring $i$ et fagfelt som burde interessere mange. Det er med svært få forbehold at jeg anbefaler den for alle kolleger med faglig eller privat interesse for lukt, smak, gastronomi, forskningshistorie, ernæringspolitikk eller simpelthen bare interesse for kunnskapsrik matlaging.

\section{Godt om kliniske undersøkelser ved funksjonsforstyrrelser}

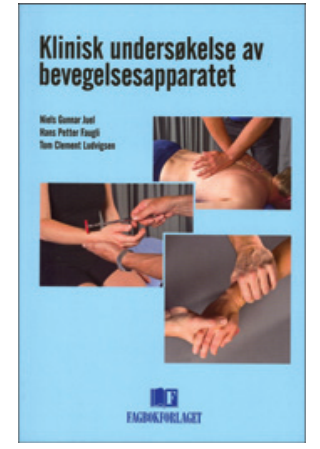

Niels Gunnar Juel, Hans Petter Faugli,

Tom Clement Ludvigsen

Klinisk undersøkelse av bevegelsesapparatet

333 s, ill. Bergen: Fagbokforlaget, 2012

Pris NOK 429

ISBN 978-82-450-1221-7

Denne boken presenteres som en basisbok i kliniske undersøkelser ved diagnostikk av plager fra bevegelsesapparatet. Forfatterne har gjort et systematisk utvalg av utallige undersøkelsesteknikker som eksisterer ved smertefulle tilstander i bevegelsesapparatet.

Boken er inndelt i 11 kapitler og har et stikkordregister som synes å stå i forhold til innholdet. Forfatterne begynner med en enkel innføring i kliniske undersøkelsesprinsipper. De beskriver i generelle termer kort testenes bakgrunn og egenskaper med tanke på validitet, sensitivitet, spesifisitet o.l. Etter hvert kapittel er det tilhørende referanser som viser til de forskjellige testenes egenskaper. Jeg synes at de forskjellige testegenskapene burde vært fremstilt noe mer i dybden, da resultater fra testene ofte utløser ytterligere diagnostikk med økende kostnader. Det synes som om utvalget av kliniske tester er mer relatert til tilstander som kan oppstå etter traumer, da psykososiale belastninger og personlige ressurser ikke blir berørt.

Hvert kapittel begynner med kasuistikker, etterfulgt av den kliniske undersøkelsen. Etter en gjennomgang av de kliniske testene for de forskjellige vevsstrukturene i det aktuelle området/leddet, avsluttes kapitlene med svar på kasuistikkene. Bildematerialet er meget godt, og kapitlene er gjennomgående systematisk oppbygd. Personlig synes jeg at det burde vært gitt noen mer utfyllende kommentarer i tolkningen av de forskjellige testresultatene.

Målgruppen er alle faggrupper som arbeider med smertefulle funksjonsforstyrrelser i bevegelsesapparatet, slik at valg, utførelse og tolkning av kliniske undersøkelser skal bli mer ensartet. Jeg synes forfatterne har oppnådd dette. Boken bør derfor godt egne seg for studenter og leger som ønsker en systematisk innføring i klinisk undersøkelse av bevegelsesapparatet. Den vil også egne seg som et oppslagsverk for dem som ønsker en enkel oppfriskning av gamle kunnskaper.

Gunnar Leivseth

Institutt for klinisk medisin

Universitetet i Tromsø 